\title{
A HÍR VÉDJEGY ISMERTSÉGE ÉS BEÁGYAZÓDOTTSÁGA A MAGYAR FOGYASZTÓK KÖRÉBEN
}

\author{
- की
THE RECOGNITION AND THE EMBEDDEDNESS OF THE TTR TRADEMARK AMONG THE HUNGARIAN CONSUMERS

\author{
- \\ $T O ̈ R O ̈ K, A ́ R O N$ \\ $-10$ \\ Budapesti Corvinus Egyetem, Gazdálkodástudományi Kar, Agrárközgazdasági és Vidékfejlesztési Tanszék \\ (Corvinus University of Budapest, Department of Agricultural Economics and Rural Development) \\ H-1093 Budapest, Fő́vám tér 8. \\ e-mail: aron.torok@uni-corvinus.hu
}

\begin{abstract}
\&
The Traditions-Tastes-Regions (TTR) programme has more than 20 years of history, promoting and economically stimulating the traditional and local food products of Hungary. Since 2002 the TTR is a registered trademark and used for product differentiation. At the end of 2018 altogether 92 producers with 176 products had the right to use the trademark. The Geographical Indications Programme - initiated by the Hungarian government in order to increase the number of the Hungarian GI products in the EU register - is also based on the TTR initiative. The demand of the Hungarian traditional food products in general, as well the supply side of the TTR programme is well described by the literature, however the field of the consumers' relation with the TTR trademark seems to be undiscovered. In spite of this background, this study tries to describe the recognition and the embeddedness of the TTR trademark among the Hungarian consumers. Part of an international survey conducted by the Strength2Food H2O2o research project, the TTR trademark was analysed on a sample of 444 Hungarian consumers, retrieved from an online survey. Results suggest that the almost $40 \%$ recognition of the TTR trademark significantly exceeds recognition of the EU geographical indications labels. However, only roughly $10 \%$ of the consumers seeks purposefully food products with TTR label. Regular buyers of such foods usually seek for meat products. Based on the binomial regression models the recognition of the TTR trademark's logo is significantly higher among female, older and non-vegetarian consumers with lower income levels. The place of regular purchase is also statistically significant: consumers with regular purchase in organic shops and in short food supply chains (directly from the producer) tend to be more aware of the TTR logo. Regarding the regular consumption of such products we can say that males and consumers shopping in supermarkets and discounters are becoming a frequent buyer of TTR products with a higher probability.
\end{abstract}

KuLCSSZAVAK: HÍR védjegy, fogyasztói felmérés, címke ismeret, rendszeres vásárlás

JEL-Kódok (JEL CODES): M31, M37, O13, O34, Q13

DOI: https://doi.org/10.20494/TM/6/1/6
KEYwORDS: TTR trademark, consumer survey,

label recognition, regular purchase 


\section{BEVEZETÉS - INTRODUCTION}

\subsection{A HÍR védjegy szerepe a magyar élelmiszergazdaságban - The Role of the TTR Trademark in the Hungarian Food Industry}

Az Európai Unió (EU), francia kezdeményezésre, 1993-ban hívta életre az „Euroterroirs” (Európa Vidékei) nevü programot, amelynek célja az európai régiók hagyományos és tájjellegü élelmiszereinek összegyüjtése, azok gazdasági hasznosításának előmozdítása, valamint ezeknek a termékeknek a fogyasztók körében való népszerüsítése volt. Az EU-csatlakozás előtt álló közép-kelet-európai országok közül Magyarország elsóként csatlakozott a programhoz 1998-ban. A „Hagyományok-Ízek-Régiók (HÍR)" kezdeményezés célja pedig az volt, hogy összegyüjtse a magyarországi hagyományos és tájjellegü élelmiszereit, s egyben hozzájáruljon azok ismertségének növeléséhez, gazdasági hasznosításukhoz (PALLÓNÉ KISÉRDI, 2003b). A HÍR program első, fogyasztók számára kézzelfogható eredménye egy kiadvány volt, amely regionális bontásban mutatta be azokat a termékeket, amelyek legalább kétgenerációs történelmi múlttal rendelkeznek, hagyományos elóállításúak, egy adott tájegységhez kötődnek, legalább az előállítás körzetében ismertséggel rendelkeznek, továbbá tényleges előállítással és forgalmazással bírnak (FARNADI, 2002). A jelentős gyüjtőmunka eredményeként a kezdeti 1148 potenciális termékből a többkörös szakértői szürés után 300 élelmiszer és 9 ásványvíz került be a HÍR gyüjteménybe (PALLÓNÉ KISÉRDI, 2003a).

A kezdeményezés iparjogvédelmi hasznosulásának lehetőségét az teremtette meg, hogy 2002 óta a „Hagyományok - Ízek - Régiók” (HÍR) színes ábrás feliratos védjegyként van bejegyezve. A védjegy tulajdonosa az agrárügyekért felelős minisztérium, használója a kezdeti években a HÍR program népszerúsítésére dedikált költségvetési forrással is rendelkező Agrár Marketing Centrum volt, amely szervezet a 2010 előtti időszakban éves költségvetésének egy jelentős részét, évente nagyságrendileg 1220 millió forintot a védjegyet támogató marketing tevékenységre fordított (TOTTH, 2007). Jelenleg a HÍR védjegyet csak az használhatja, aki megfelel az önkéntes minőségrendszer kritériumainak és az Agrárminisztériummal erről védjegyhasználati szerződést kötött.

LAKNER és szerzőtársai (2009) szerint a HÍR védjegyes élelmiszerek mindenképpen a termék-különlegességek csoportjába sorolhatók. Továbbá a HÍR program, illetve a HÍR védjegy az úgynevezett Hungarikum törvény (2012. évi XXX. törvény) létrejöttéhez is mintául szolgált. A hagyományos magyar élelmiszerek szervezett koordinációját a HÍR program hivatott szolgálni (BIACS és SZIGETI, 2006), s a kezdeményezés a hungarikumok hivatalos kijelölésének előfutára volt (ÁLDORFAI és CZABADI, 2014). Fontos ugyanakkor kiemelni, hogy a „Hungarikum” 2013-ban színes ábrás védjegyként bejegyzésre került, jogosultja az Agrárminisztérium. A „Hungarikum” védjegy használati jogát azonban eddig kevés termék nyerte el. Az agrártermékek esetében a termelők/előállítók számára már maga a hungarikummá nyilvánítás a vágyott és legmagasabb szintű elismerésnek számít.

A HÍR védjegy stratégiai jelentőségét továbbá az adja, hogy potenciálisan ezek a termékek az EU élelmiszer minőségpolitika zászlóshajójának számító földrajzi árujelzők várományosainak is tekinthetők. A földrajzi területhez köthető, hagyományos termékek különleges minőségének fogyasztókban való tudatosítása kiemelkedően fontos, amihez az EU-s eredetvédelem újabb lehetőséget biztosít (POPOVICS és GYENGE, 2005). A hagyományos és tájjellegű (HÍR védjegyes) termékek ezen az úton alapvetően kétféle módon szerezhetnek nagyobb ismertséget, akár Európa szerte. A szoros földrajzi kötődés (akár a termék minőségén, vagy annak ismertségén keresztül) az eredetvédelmi rendszerben oltalmazható (oltalom alatt álló eredetmegjelölés, vagy oltalom alatt álló földrajzi jelzés formájában), míg amennyiben inkább a hosszú múltra visszatekintő, hagyományos előállítási mód a meghatározó, úgy hagyományos különleges termékként lehet közösségi szinten elismertetni a terméket (ZOBOR, 2010). A 2015-ben a Földmüvelésügyi Minisztérium által indított Eredetvédelmi Program (ami ma már a Földrajzi Árujelzők Programja néven fut) eredményeként az uniós oltalomra benyújtott 14 magyar kérelem közül 6 termék HÎR védjeggyel is rendelkezik 
(DARVASNÉ ÖRDÖG, 2018). A minisztérium legfrissebb adatközlése szerint 2018. december 31-ig 31 magyar kérelem került benyújtásra az Európai Bizottsághoz és ezek közül 14 HÍR védjegyes termék (PALLÓNÉ KISÉRDI, 2019).

\subsection{A HÍR védjegyes termékek kínálati oldala - The Supply Side of the Products with TTR Trademark}

Az Agrárgazdasági Kutató Intézet 2012 óta minden évben felméri a HÍR védjegyes termékek helyzetét, így a HÍR védjegy kínálati oldaláról naprakész és részletes adatok állnak ren- delkezésre. Ezek alapján megállapítható, hogy az elmúlt időszakban évente átlagosan 6-7 új termelő szerez jogosultságot átlagosan 13 termékkel, azonban a korábban már említett Eredetvédelmi Program következtében 2016-ban kiugrás volt tapasztalható (lásd 1. ábra) 24 termékkel. Jelenleg mindösszesen 176 db HÍR védjegyes termékre vonatkozóan van védjegyhasználati szerződés kötve, mely összesen 92 védjegyhasználati jogosultat (termelő, csoportosulás) jelent, közülük pedig 76 volt 2018-ban is aktív védjegyhasználó (DARVASNÉ ÖRDÖG, 2018).

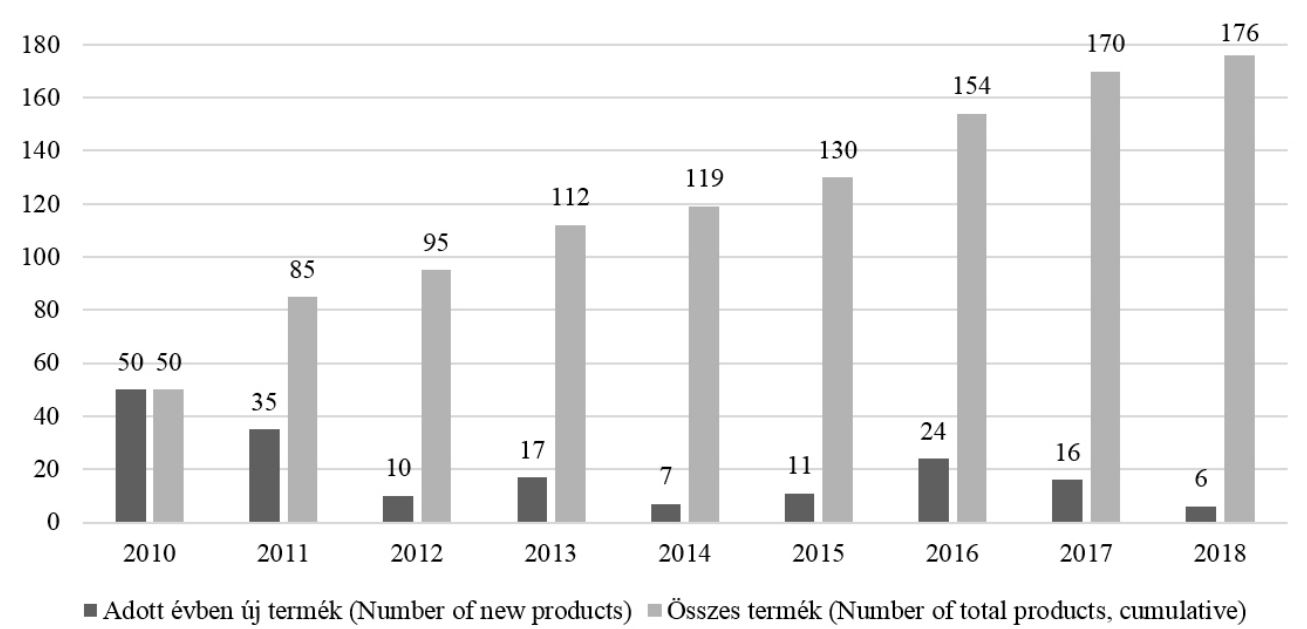

1. ÁBRA

A Hír védjegyes termékek számának alakulása, db (Number of TTR Products, piece)

Forrás (Source): DARVASNÉ ÖRDÖG (2018)

A jelenlegi HíR védjegyes termékek termékcsoportok szerinti eloszlása nagyfokú koncentrációt mutat (lásd 1. táblázat). Minden harmadik HÍR védjegyes termék sütőipari ter- mék, s 10\% feletti a részaránya az italoknak is. Halászati termékekből, illetve olajokból és zsírokból ugyanakkor mindösszesen 1-1 termék tartozik ebbe a körbe. 
TöröK, Á.

1. TÁBLÁZAT

TABLE 1

HÍR védjegyes termékek száma termékkategóriánként

(Number of TTR Products in the Product Categories)

\begin{tabular}{|c|c|c|}
\hline $\begin{array}{l}\text { Termékkategóriák } \\
\text { (Product category) }\end{array}$ & $\begin{array}{l}\text { Védjegyes } \\
\text { termékek } \\
\text { száma, db } \\
\text { (Number of } \\
\text { products) }\end{array}$ & $\begin{array}{l}\text { Részarány, } \\
\text { \% (Share, \%) }\end{array}$ \\
\hline Sütőipari termékek (Bakery products) & 58 & 33 \\
\hline Italok, beleértve a szörpöket (Beverages, including sirups) & 20 & 11 \\
\hline Tejtermékek (Dairy products) & 16 & 9 \\
\hline $\begin{array}{l}\text { Friss vagy feldolgozott zöldségek, gombák (Fresh or processed vegetables, } \\
\text { mushrooms) }\end{array}$ & 14 & 8 \\
\hline Húsok, húskészítmények (Meat products) & 14 & 8 \\
\hline Tájjellegú ételek (Local foods) & 14 & 8 \\
\hline Friss vagy feldolgozott gyümölcsök (Fresh or processed fruits) & 13 & 7 \\
\hline Méz (Honey) & 8 & 5 \\
\hline Édesipari termékek (Sweet products) & 5 & 3 \\
\hline Fúszernövények, gyógynövények, ízesítők (Spices, herbs and flavors) & 5 & 3 \\
\hline Száraztészták (Pastas) & 4 & 2 \\
\hline Cukrászati termékek (Confectioneries) & 3 & 2 \\
\hline Halászati termékek (Fishery products) & 1 & 1 \\
\hline Olajok és zsírok (Oils and fats) & 1 & 1 \\
\hline Összesen (Total) & 176 & \\
\hline
\end{tabular}

Forrás (Source): Saját szerkesztés DARVASNÉ ÖRDÖG (2018) alapján (Own compilation based on DARVASNÉ ÖRDÖG (2018))

A legutóbbi felmérés (DARVASNÉ ÖRDÖG, 2018) eredményei alapján a HÍR védjegyet használók leginkább a termékcímkén, csomagoláson (66\%), az üzlet vagy a rendezvény helyszínén (62\%-62\%) jelenítik meg a védjegyet, míg legkevésbé az online felületeken (csoportosulás honlapja 40\%, saját honlap $54 \%$ ) használják azt. A termelők visszajelzése alapján a védjegy megjelenítésének leginkább pozitív hatása a rendezvények helyszínén való megjelenítésnek van, amit szintén alátámaszt az a tény, hogy a HÍR védjegyes termékek leginkább közvetlen értékesítésen keresztül jutnak el a fogyasztókhoz (lásd 2. táblázat), míg a legkevésbé az élelmiszer diszkontokban. Fontos ugyanakkor kiemelni, hogy amennyiben egy HÍR védjegyet használó termelő egy multi beszállítójává válik, úgy akár a teljes értékesítési volumenének több mint felét is itt realizálja. Ilyen szempontból jelentős még a helyi termelői piacok, és a különböző rövid élelmiszerellátási láncok volumene. Ugyanakkor az online értékesítés részaránya marginális, amit okozhat az is, hogy a HÍR védjegyes termékek közül több is rövid lejárati idővel rendelkezik és nehezen szállítható, ami nem teszi lehetővé ennek a modern értékesítési csatornának a használatát (DARVASNÉ ÖRDÖG, 2016). Öszszességében pedig elmondható, hogy egy tipikus HÎR védjegyes termelő összes árbevételének átlagosan $25 \%$-át teszi ki a HÍR védjegyes termék (DARVASNÉ ÖRDÖG, 2017). 
2. TÁBLÁZAT

TABLE 2

A Hír védjegyes termékek értékesítési csatornái és azok részaránya az értékesítésből (Sales Channels of TTR Products and Their Share in Total Sale)

\begin{tabular}{|c|c|c|}
\hline & $\begin{array}{c}\text { Említési } \\
\text { gyakoriság } \\
\text { (Frequency of } \\
\text { mention) }\end{array}$ & $\begin{array}{c}\text { Részarány az } \\
\text { értékesítésből, } \\
\% \text { (Share in } \\
\text { total sales, \%) }\end{array}$ \\
\hline $\begin{array}{l}\text { Közvetlen értékestés a fogyasztónak (pl.: piac, rendezvény, házhozszállítás) } \\
\text { (Direct sale to end consumers, e.g.: market, fairs, home delivery) }\end{array}$ & 32 & 39 \\
\hline Független kisbolt (Independent small sized shop) & 18 & 25 \\
\hline Vendéglátás (pl.: étterem, szálloda) (HoReCa) & 16 & 37 \\
\hline Helyi termelői piac (Local farmers' market) & 13 & 44 \\
\hline Nagykereskedő (Wholesale) & 9 & 26 \\
\hline $\begin{array}{l}\text { Magyar tulajdonú lánc (pl.: Coop, CBA, Reál) (Hungarian chain, e.g. Coop, CBA, } \\
\text { Reál) }\end{array}$ & 8 & 19 \\
\hline Webshop (e-kereskedelem) (Webshop, e-commerce) & 6 & 5 \\
\hline Export (Export) & 6 & 17 \\
\hline Feldolgozóipar (Food processing industry) & 5 & 20 \\
\hline $\begin{array}{l}\text { Szuper-/hipermarket lánc (pl.: Tesco, Spar, Auchan) (Super/hypermarket chain } \\
\text { e.g. Tesco, Spar, Auchan) }\end{array}$ & 3 & 52 \\
\hline $\begin{array}{l}\text { Beszerzési társulás (pl.: Metspa, Provera) (Purchasing association, e.g. Metspa, } \\
\text { Provera) }\end{array}$ & 3 & 12 \\
\hline $\begin{array}{l}\text { Intézményi vevő (pl.: kórház, iskola stb.) (Public sector catering, e.g. hospital, } \\
\text { school etc,) }\end{array}$ & 2 & 21 \\
\hline $\begin{array}{l}\text { Diszkont (pl.: Penny Martket, Lidl, Aldi) (Food discounter, e.g. Penny Market, } \\
\text { Lidl, Aldi) }\end{array}$ & 1 & 14 \\
\hline
\end{tabular}

Forrás (Source): Saját szerkesztés DARVASNÉ ÖRDÖG (2018) alapján (Own compilation based on DARVASNÉ ÖRDÖG (2018))

\subsection{A hagyományos magyar élelmisze- rek kereslete - The Demand of the Traditional Hungarian Food Products}

A hagyományos magyar élelmiszerek keresleti oldalát többen is vizsgálták már Magyarországon. POPOVICS és PALLÓNÉ KISÉRDI (2004) fogyasztói felmérése alapján a fogyasztók leginkább azokat a termékeket tekintik hagyományos magyar élelmiszernek, amelyek az idő- (már a nagyszülei is ismerték) és helydimenzióban (magyarországi alapanyagból készül) különülnek el a többi terméktől. A HíR gyüjtemény relevanciáját az is alátámasztotta, hogy a fogyasztók számos olyan terméket neveztek meg spontán hagyományos magyar terméknek, amelyek már korábban bekerültek a gyüjteménybe (pl.: kalocsai és szegedi füszerpaprika, gyulai kolbász, makói hagyma).

Hagyományos és tájjellegü húskészítményeket vizsgálva SZABÓ (2006) azt találta, hogy a fiatalabb korosztály ismeretei és elköteleződöttsége az ilyen termékek irányába alacsonyabb az idősebbekhez képest, továbbá hogy a férfiak jobban preferálják ezeket a készítményeket, bár fizetési hajlandóságban nincs különbség köztük és a nők között. Végzettség szempontjából azt találta, hogy a felsőfokú oklevéllel rendelkezőknek a legkedvezőbb a megítélése ezen termékek iránt. Ugyanezen szerző későbbi felmérése a hagyományos és tájjellegü termékek fogyasztói asszociációit a korábban már beazonosított tér és idő dimenzió mellett kiegészítette a hagyományos készítésmóddal, továbbá megállapította, hogy a 45 év feletti fogyasztók a leginkább nyitottak a regionális termékek irányában (SZABÓ, 2009).

SZAKÁLY és szerzőtársai (2008a) egy országosan reprezentatív mintán végeztek kérdőíves felmérést a hagyományos magyar élelmiszerek keresletének feltérképezéséhez. Eredményeik szerint a magyarok döntő több- 
sége fogyaszt ilyen élelmiszert, leginkább a képzettebbek és magasabb jövedelemmel rendelkezők vásárolnak gyakran, s ez a szegmens akár a magasabb árat is hajlandó megfizetni. A megkérdezettek 80\%-a preferálná azokat a hagyományos magyar élelmiszereket, amelyeket védjeggyel látnak el. A tipikus vásárlási helyszín a kisebb élelmiszerboltok, hiper- és szupermarketek voltak 2008-ban (42-46\%), ugyanakkor a közvetlenül a termelőtől való beszerzés (15\%) megelőzte a diszkontokat (14\%). Ugyanezen szerzők (SZAKÁLY et al., 2008b) eredményei alapján megállapítható, hogy a hagyományos magyar termékek egy elöregedő, inkább férfiakat megszólító termékcsoportnak tekinthetőek, azonban célzott marketinggel a fontolva haladó, a fiatal trendkövető és a változatosságot kereső érett fogyasztói csoportok is megszólíthatóak.

POPOVICS (2009) szerint a magyar fogyasztók kifejezetten gyakran (naponta, vagy hetente) vásárolnak olyan terméket, amelyet saját maguk értelmezése szerint hagyományos magyar élelmiszernek tartanak.

A magyarországi élelmiszer minőségi rendszerek átfogó vizsgálata során JUHÁSZ és szerzőtársai (2010) megállapították, hogy a HÍR védjegy a Kiváló Magyar Élelmiszer tanúsító védjeggyel együtt a legrégebbi müködő nemzeti fogyasztói minőségi rendszert jelentik, s előbbinek különösen a malomipari termékek, illetve az italgyártás területén van nagy jelentősége.

Női fogyasztókat, mint az élelmiszertermékek beszerzéséért Magyarországon leginkább felelős vásárlókat, vizsgáló kutatásukban DOGI és szerzőtársai (2014) azt találták, hogy nagy igény jelentkezik a kézmưves élelmiszerek eredetmegjelölésére, $\mathrm{s}$ az ilyen termékekért akár felárat is hajlandóak fizetni a fogyasztók. A vásárlási gyakoriságot tekintve a fogyasztók gyakran vásárolnak ilyen élelmiszereket, azonban az online csatorna használata még nem elterjedt, továbbá a hipermarketek ilyen típusú élelmiszereinek kínálata meglehetősen szúkös.

SZÉKELYHIDI és szerzőtársai (2014) illetve DARVASNÉ és szerzőtársai (2014) a HÍR védjegy fogyasztói ismertségét vizsgálva meglehetősen alacsony, mindösszesen $5 \%$-os értéket mértek. Véleményük szerint az alacsony ismertség oka az élelmiszerkereskedelemben használt védjegyek túl nagy száma, illetve a HÍR védjegyhez kapcsolódó célzott marketing hiánya lehet. TOTTH és szerzőtársai (2015) ugyanakkor ennél jóval magasabb, 16\%-os (rásegítéses) ismertséggel szembesültek, továbbá az általuk megkérdezett minta alapján a magyar fogyasztók 9\%-a ismerte és egyben vásárolta is a HÍR védjeggyel ellátott termékeket.

$\mathrm{Az}$ egyik legátfogóbb, élelmiszercímkék használatának magyarországi vizsgálatára 2014-ben került sor (SZAKÁLY et al., 2014). Az országosan is reprezentatívnak tekinthető minta alapján a szerzők megállapították, hogy a magyar fogyasztók jelentős része $(83,3 \%$-a) megnézi az élelmiszereken szereplő címkéket, $\mathrm{s}$ átlagosan 41 másodpercet tölt annak tanulmányozásával (meghaladva az EU átlag 30 másodpercet). Legkevesebb időt a pékáruk, péksütemények címkéinek tanulmányozásával töltenek a fogyasztók, míg legtöbbet az ismeretlen termékek mellett a húskészítményekre fordítanak. A fogyasztók leginkább az árat, minőség-megőrzési időt és a termék nevét keresik a csomagoláson, míg a származási helyet és a különböző védjegyeket, jelöléseket kevésbé. Az iskolai végzettség vizsgálatakor megállapították, hogy minél iskolázottabb egy vásárló, annál valószínúbb, hogy megnézi vásárláskor az összetevők listáját, az adalékanyag-tartalmat és a származási helyet. Ugyan a HÍR védjegy ismertségének mérésére a felmérés külön nem tért ki, az eredményekből kiemelendő, hogy az oltalom alatt álló földrajzi jelzést egyetlen fogyasztó sem említette meg spontán, mint olyan jelölést, amely az élelmiszer minőségére, vagy az eredetre utal, $\mathrm{s}$ rásegítéssel is mindösszesen 4,5\%-os volt az arány.

JASÁK és szerzőtársai (2014) továbbá rámutattak arra, hogy a hagyományos és tájjellegű élelmiszerek kapcsán a fogyasztók fejében egyfajta káosz uralkodik, ugyanis különösen a hungarikum elnevezés törvényi szabályozása utáni állapotokat tekintve annak komplex jelentéstartalmával a fogyasztók nincsenek tisztában, így beazonosítani sem tudják egyértelmüen azokat.

A fenti szakirodalmi összegzés alapján jelen tanulmány arra keresi a választ, hogy a HÍR védjegy mennyire ismert a magyar fogyasztók körében, s az ehhez a jelöléshez kapcsolódó viszonyukat milyen tényezők befolyásolják. 
2. ANYAg ÉS MÓDSZER - MATERIAL AND METHODS

\subsection{Mintavétel - Sampling}

A felhasznált adatok online lekérdezése 2017 második felében történt, a Strength2Food H2020 nemzetközi kutatás ${ }^{1}$ keretein belül, a nemzetközi LighSpeed Research piackutató vállalat bevonásával. Az EU-s földrajzi árujelzős, valamint a közösségi bio címkéken túl a magyar mintán a HÍR és a KMÉ védjegyhez kapcsolódó lekérdezés történt meg.

A 3. táblázat foglalja össze a válaszadók legfontosabb ismérveit. A HÍR védjegyhez kap- csolódó lekérdezés az adattisztítás és a szűrés (csak a vásárlásért legalább részben felelős fogyasztók válaszai kerültek kiértékelésre) után 444 értékelhető választ eredményezett. A reprezentativitást tekintve elmondható, hogy a nem és az életkor tekintetében a minta közel reprezentatív, ugyanakkor a lakóhely esetében a községből származó válaszadók jelentősen alul-, míg a városiak felülreprezentáltak. Ez utóbbiakat leginkább a lekérdezés online volta magyarázza. Továbbá a mintán jelentős torzítás figyelhető meg a gyerekek számában: a kérdőívet kitöltők jelentősen kevesebb gyerekkel rendelkeztek, mint a magyarországi átlag.

A felméréshez használt minta legfontosabb paraméterei (The Most Important Characteristics of the Survey)

\begin{tabular}{lcc}
\hline & $\begin{array}{c}\text { Felmérés } \\
\text { (Survey) }\end{array}$ & $\begin{array}{c}\text { KSH } \\
\text { (Last census) }\end{array}$ \\
\hline Összes válaszadó/Népesség (Total respondants/population) & 514 & 9937628 \\
\hline Bevont válaszadó (Respondant included) & 444 & - \\
\hline Nem (Gender) & & 52,52 \\
\hline Nő (\%) (Women,\%) & 50,45 & 47,48 \\
\hline Férfi (\%) (Men) & 49,55 & 41,39 \\
\hline Átlagos életkor (Average age) & 41,12 & 30,53 \\
\hline Lakóhely (Location) & 19,6 & 34,35 \\
\hline Község (\%) (Rural) & 38,96 & 35,13 \\
\hline Város (\%) (Small city) & 41,44 & $222097^{*}$ \\
\hline Nagyváros (\%) (Big city) & 255694 & 1,07 \\
\hline Háztartás átlagos jövedelme (Ft) (Average family income, HUF) & 0,65 & \\
\hline Gyerekek száma (fö) (Number of children) & & \\
\hline
\end{tabular}

Forrás (Source): Saját szerkesztés a felmérés és KSH, 2013 alapján (Own compilation based on KSH, 2013)

* a népszámlálási adat korrigálva a fogyasztói árindexekkel (data from last census adjusted by the CPIs)

\subsection{Adatelemzés - Statistical Analysis}

A leíró statisztikai elemzéseken túl binomiális logisztikus regressziós számítások kerültek elvégzésre annak érdekében, hogy megértsük, hogy a magyar fogyasztók esetében mi magyarázhatja azt, hogy valaki ismeri-e az HÍR védjegyet, továbbá mi állhat annak a hátterében, ha valaki rendszeresen vásárol ilyen élelmiszereket (és így az elmúlt 2 hétben is vett HÍR védjegyes terméket). A szakirodalom által korábban ${ }^{1}$ https://www.strength2food.eu/ vizsgált paraméterek függvényében öt szocio-demográfiai és -ökonómiai változót (nem, életkor, lakóhely, jövedelem, gyerekek száma) teszteltünk a saját mintánkon, továbbá a fogyasztók tipikus vásárlási helyszínének, illetve étrendjének a hatása is megvizsgálásra került.

Ezek alapján a logisztikus regressziós modellek az alábbiak szerint épülnek fel:

$\operatorname{Pr}($ Ismeri a HÍR védjegyet $=1)=\mathrm{F}(\beta \mathrm{O}+$ $\beta 1 \mathrm{Nem}+\beta_{2}$ Életkor $+\beta 3$ Lakóhely $+\beta 4$ Jövedelem $+\beta 5$ Gyerekek száma $+\beta 6$-15Vásárlási 
TöröK, Á.

helyszín + ß16-19Étrend)

$\operatorname{Pr}($ Rendszeres vásárló $=1)=\mathrm{F}(\beta \mathrm{O}+\beta 1 \mathrm{Nem}$ $+\beta 2$ Életkor $+\beta 3$ Lakóhely $+\beta 4$ Jövedelem + $\beta 5$ Gyerekek száma + $\beta 6$-15Vásárlási helyszín + $\beta 16$-19Étrend).
Az egyes változók részletes bemutatását a 4. táblázat ismerteti.

4. TÁBLÁZAT

A binomiális logisztikus regressziós modellek változóinak leírása

TABLE 4 (Variables Included to the Binomial Regression Model)

\begin{tabular}{|c|c|}
\hline Ismeri a HÍR védjegyet (Recognition of the TTR logo) & $\begin{array}{l}\text { Értéke 1, amennyiben a válaszadó (spontán) azt állítja, } \\
\text { hogy ismeri a címkét, egyébként o }\end{array}$ \\
\hline Rendszeres vásárló (Frequent buyer) & $\begin{array}{l}\text { Értéke 1, amennyiben a fogyasztó a lekérdezést megelőző } 2 \\
\text { hétben is vásárolt ilyen terméket, egyébként o }\end{array}$ \\
\hline Nem (Gender) & Értéke 1, amennyiben a válaszadó nő, egyébként o \\
\hline Életkor (Age) & A válaszadó életkora \\
\hline Lakóhely (Location) & A válaszadó lakóhelye (község/város/nagyváros) \\
\hline Jövedelem (Income) & $\begin{array}{l}\text { A vásárló háztartásának együttes havi jövedelmi kategóriá- } \\
\text { ja (ezer HUF: <150/150-205/205-235/235-380/380-835/ } \\
835>\text { ) }\end{array}$ \\
\hline Gyermekek száma (Number of children) & $\begin{array}{l}\text { A válaszadó háztartásában élő } 18 \text { éven aluli gyermekek } \\
\text { száma }\end{array}$ \\
\hline Vásárlási helyszín1-10 (Shopping location) & $\begin{array}{l}\text { A leggyakoribb élelmiszer vásárlási helyszín (szupermarket, } \\
\text { diszkont, kisbolt, termelői piac, áruház, hipermarket, bio-- } \\
\text { bolt, internet, közvetlenül a termelőtől, egyéb alternatív) }\end{array}$ \\
\hline Étrend1-4 (Diet) & $\begin{array}{l}\text { A válaszadó étrendje (Fogyaszt valamilyen: tejterméket/ } \\
\text { halat/hústerméket/tojást) }\end{array}$ \\
\hline
\end{tabular}

Forrás (Source): Saját szerkesztés (Own compilation)

Összességében a tanulmány az alábbi kérdésekre keresi a választ:

- A magyar fogyasztók mennyire ismerik a HÍR védjegyet, s mi jellemzi azokat a fogyasztókat, akik ismerik azt?

- Az egyes fogyasztók mennyire veszik figyelembe az élelmiszer vásárlási döntéseiknél a HÍR védjegyet, $\mathrm{s}$ ha nem veszi figyelembe, akkor annak mi az oka?

- A fogyasztók mekkora hányada vásárol rendszeresen HíR védjegyes terméket? Ha vásárol ilyen terméket, akkor mit vett, illetve ha nem vásárolt, akkor miért nem?

- Milyen tényezók játszanak abban szerepet, hogy valaki ismeri a HÍR védjegyet, illetve rendszeresen vásárolja az ilyen tanúsítással ellátott termékeket?

\section{EREDMÉNYEK - RESUlTS}

\subsection{A HÍR védjegy ismertsége - The Recognition of the TTR Trademark}

Az online lekérdezés azon kérdésére, miszerint ismeri-e a válaszadó a kérdés alatt megjelenített HÍR védjegyet, a megkérdezettek 39,64\%-a igennel felelt. Ugyanakkor arra a kérdésre, hogy a címkét ismerő fogyasztó mennyire veszi tudatosan figyelembe a HÍR logót, a megkérdezettek több mint 60\%-a csak az eseti jelleget választotta, alig több mint minden 10. fogyasztó keresi tudatosan a HÍR védjeggyel ellátott termékeket vásárlásai során (2. ábra). 


\section{A HÍR VÉDJEGY ISMERTSÉGE ÉS BEÁGYAZÓDOTTSÁGA A MAGYAR FOGYASZTÓK KÖRÉBEN}

\section{2. ÁBRA}

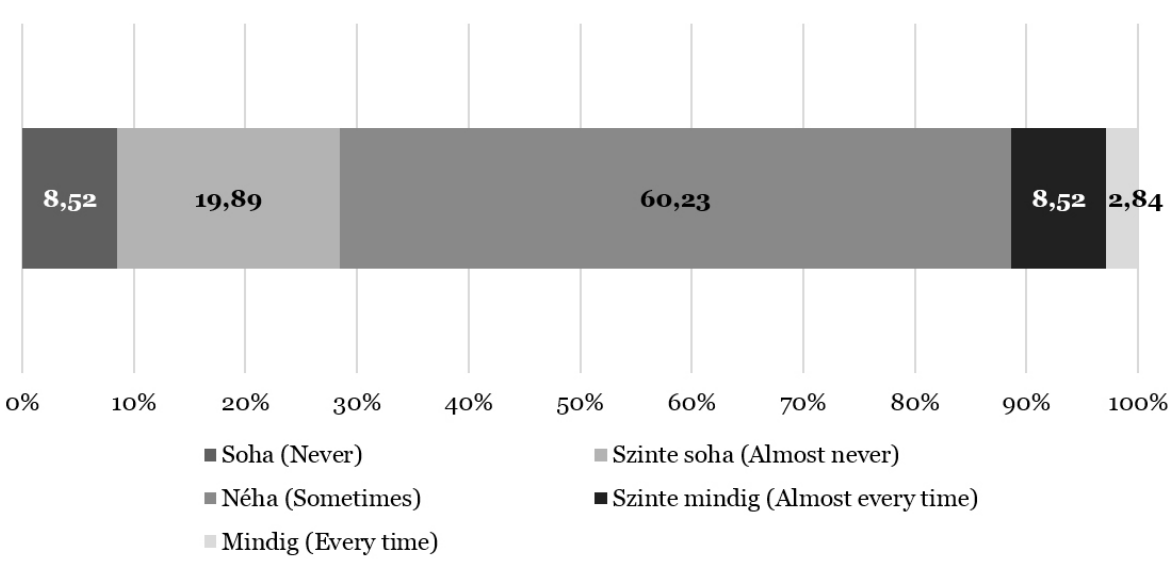

A HÍR védjegy figyelembevétele élelmiszer vásárlás során

FIG. 2 (Considering the TTR Logo for Food Purchase)

Forrás (Source): Saját szerkesztés a felmérés alapján (Own compilation based on the survey)

Azok a fogyasztók, aki soha, vagy szinte soha nem keresik a HÍR védjegyet, leginkább a jelölésekkel kapcsolatos szkepticizmusát, illetve az azok tanulmányozására fordított idő hiányát jelölték meg leggyakoribb indokként. Minden 10. fogyasztó ugyanakkor a HÍR védjegyes termékek rossz elérhetőségét is megjelölte (5. táblázat).

A HÍR védjegy figyelmen kívül hagyásának leggyakoribb indokai (Reasons for Neglecting TTR Logo)

\begin{tabular}{lc}
\hline \multicolumn{1}{c}{$\begin{array}{c}\text { Indokok } \\
\text { (Reasons) }\end{array}$} & $\begin{array}{c}\text { Említési } \\
\text { gyakoriság, \% } \\
\text { (Frequency of } \\
\text { mention, \%) }\end{array}$ \\
\hline Általánosságban nem hisz a jelölésekben (Doesn't trust labels in general) & $\begin{array}{c}\text { mente } \\
\text { Vásárlás során nincs idő a jelölésekkel foglalkozni (Doesn't have time to consider labels) }\end{array}$ \\
\hline $\begin{array}{l}\text { Ritkán fordít figyelmet élelmiszer bevásárlása során a jelöléssel rendelkező termékekre (Rarely pays } \\
\text { attention to products with labels) }\end{array}$ & 14 \\
\hline $\begin{array}{l}\text { Kevés a jelöléssel rendelkező termékek választéka a boltban, ahol vásárol (There are only few } \\
\text { varieties of products with this label in stores where doing grocery shopping) }\end{array}$ & 13 \\
\hline $\begin{array}{l}\text { Nem tudja, hogy hol keresse az ezzel a jelöléssel ellátott termékeket (Doesn't know where to buy } \\
\text { products with this label) }\end{array}$ & 10 \\
\hline
\end{tabular}

Forrás (Source): Saját szerkesztés a felmérés alapján (Own compilation based on the survey) 
TöröK, Á.

\subsection{A HÍR védjegyes termékek keres-}

lete - The Consumption of the Food

Products with TTR Trademark

A megkérdezett fogyasztók 38,88\%-a vásárolt a felmérést megelőző két hétben valamilyen
HÍR védjegyes élelmiszert, leginkább valamilyen feldolgozott hústerméket, de a sajtok és tejtermékek, illetve a feldolgozott gyümölcs, és zöldségfélék és a friss húskészítmények részaránya is magas volt (6. táblázat).

A leggyakrabban vásárolt HÍR védjegyes termékek (The Most Often Purchased TTR Products)

\begin{tabular}{lc}
\hline \multicolumn{1}{c}{$\begin{array}{c}\text { Termékcsoport } \\
\text { (Product category) }\end{array}$} & $\begin{array}{c}\text { Említési } \\
\text { gyakoriság, \% } \\
\text { (Frequency of } \\
\text { mention, \%) }\end{array}$ \\
\hline $\begin{array}{l}\text { Feldolgozott hús (sonka, kolbász, füstölt hús, stb.) (Processed meat products, e.g. ham, sausage, } \\
\text { smoked meat etc.) }\end{array}$ & 16 \\
\hline Sajtok (Cheese) & 9 \\
\hline Tej (Milk) & 9 \\
\hline Feldolgozott gyümölcs-, zöldségfélék (Processed fruits and vegetables) & 8 \\
\hline Friss hús (Fresh meat) & 8 \\
\hline
\end{tabular}

Forrás (Source): Saját szerkesztés a felmérés alapján (Own compilation based on the survey)

A válaszadók szerint annak az oka, hogy az elmúlt két hétben nem vásároltak HÍR védjegyes terméket, leginkább a kínálat elégtelen volta a magyarázat, viszont a HÍR védjegyes termékek esetleges felárát csak a fogyasztók 7\%-a jelölte meg indokként (7. táblázat).

A HÍR védjegy figyelmen kívül hagyásának leggyakoribb indokai a címkét ismerôk között (Reasons for Neglecting TTR Logo Among Consumers Familiar with the TTR Logo)

\begin{tabular}{|c|c|}
\hline $\begin{array}{l}\text { Indokok } \\
\text { (Reasons) }\end{array}$ & $\begin{array}{c}\text { Említési } \\
\text { gyakoriság, \% } \\
\text { (Frequency of } \\
\text { mention, \%) }\end{array}$ \\
\hline Nem volt lehetősége az elmúlt 2 hétben (Lack of opportunity in the last 2 weeks) & 29 \\
\hline $\begin{array}{l}\text { Kevés a jelöléssel rendelkező termékek választéka a boltban, ahol vásárol (There are only few } \\
\text { varieties of products with this label in stores where doing grocery shopping) }\end{array}$ & 20 \\
\hline $\begin{array}{l}\text { Ritkán fordít figyelmet élelmiszer bevásárlás során a jelöléssel rendelkező termékekre (Rarely pays } \\
\text { attention to products with labels) }\end{array}$ & 10 \\
\hline $\begin{array}{l}\text { Nem tudja, hogy hol keresse az ezzel a jelöléssel ellátott termékeket (Doesn't know where to buy } \\
\text { products with this label) }\end{array}$ & 9 \\
\hline Ezzel a jelöléssel jelzett termékek túl drágák (Products with this label are too expensive) & 7 \\
\hline Vásárlás során nincs idő a jelölésekkel foglalkozni (Doesn’t have time to consider labels) & 7 \\
\hline
\end{tabular}

\subsection{A regressziós modellek eredményei}

- Results of the Regression Models

A HÍR védjegy ismertségét számos tényező statisztikailag is kimutatható módon befolyásolja. $\mathrm{Az}$ eredmények alapján elmondható, hogy a nők körében ismertebb a logó, míg az idősebb korosztály számára szintén jobban ismert ez a fajta címke. A jövedelemnél ugyanakkor fordított a kép: minél magasabb jövedelmi kategóriába tartozik egy fogyasztó, annál kisebb az esélye annak, hogy ismeri azt. Számos értékesítési csatorna pozitívan befolyásolja a címke ismertségét, a bioboltokban, valamint a köz- 
vetlenül a termelőktől vásárlók sokkal jobban ismerik a címkét, mint azok, akik ilyen helyeken nem vásárolnak. A bioboltok eredményét az magyarázhatja, hogy itt jellemzően amúgy is a tudatosabb vásárlói réteg fordul meg leginkább, akik a különböző bio tanúsítások mellett az egyéb élelmiszer jelzésekkel is tisztában vannak. Az étrend szempontjából két csoport is meghatározónak bizonyult, azok a fogyasztók, akik húst is esznek, több mint háromszoros valószínűséggel ismerik a védjegyet, mint azok, akik vegetáriánusok. Mivel a HíR védjegyes termékek között számos húsféle található, s ez a termékcsoport a leginkább keresett ezzel a tanúsítással (lásd 6. táblázat), ezért ez az eredmény indokolt. Ugyanakkor a tojás fogyasztása csökkenti annak az esélyét, hogy valaki ismerje ezt a tanúsítást (8. táblázat). Ez utóbbi - némiképp meglepő - eredmény értelmezése ugyanakkor további vizsgálatot igényelne, amire a jelen kutatás nem terjed ki.

A HÍR védjegy ismertségét meghatározó tényezők (Determinants of TTR Label Recognition)

\begin{tabular}{lcc}
\hline $\begin{array}{l}\text { Függó változó } \\
\text { (Dependent } \\
\text { variable) }\end{array}$ & $\begin{array}{c}\text { Magyarázó változók } \\
\text { (Independent variables) }\end{array}$ & $\begin{array}{c}\text { Esélyhányadosok, zárójelben az } \\
\text { értékek (Odds ratios, z-values in } \\
\text { parentheses) }\end{array}$ \\
\hline $\begin{array}{l}\text { Ismeri a HÍR } \\
\text { védjegyet } \\
\text { (Recognizes the } \\
\text { TTR label) }\end{array}$ & Nem (Gender) & $1,621(2,13)^{* *}$ \\
\cline { 2 - 3 } & Életkor (Age) & $1,014(1,67)^{*}$ \\
\cline { 2 - 3 } & Kisbolt (Convenience store) & $0,891(1,78)^{*}$ \\
\cline { 2 - 3 } & Termeloói piac (Farmers'market) & $1,684(1,95)^{*}$ \\
\cline { 2 - 3 } & Áruház (Department store) & $1,621(1,83)^{*}$ \\
\cline { 2 - 3 } & Hipermarket (Hypermarket) & $1,863(2,15)^{* * *}$ \\
\cline { 2 - 3 } & Biobolt (Organic shop) & $1,604(1,83)^{*}$ \\
\cline { 2 - 3 } & Közvetlenül a termelőtól (Directly from farmer) & $3,179(2,27)^{* *}$ \\
\cline { 2 - 3 } & Fogyaszt hústerméket (Eats some types of meat) & $2,490(2,66)^{* * *}$ \\
\cline { 2 - 3 } & Fogyaszt tojást (Eats eggs) & $3,283(1,99)^{* *}$ \\
\hline
\end{tabular}

Forrás (Source): Saját szerkesztés (Own compilation)

Szignifikancia szintek (Levels of significance): * $\mathrm{p}<0,1 ;{ }^{* *} \mathrm{p}<0,05 ;{ }^{* * *} \mathrm{p}<0,01$

Megjegyzés (Notes): A táblázat csak a szignifikáns eredményeket tartalmazza (Table contains only the significant results)

A HÍR védjegy ismertségével szemben az ilyen jelöléssel ellátott termékek rendszeres vásárlását mindösszesen három tényező határozza meg szignifikáns módon (9. táblázat). Ugyan a címkét a nők jobban ismerik, a férfi fogyasztók sokkal inkább válnak rendszeres vásárlóivá az ilyen védjeggyel ellátott termékeknél. Erre magyarázatul szolgálhat, hogy a leginkább elérhető HÍR védjegyes termékek feldolgozott húskészítmények, amelyek inkább a férfi vásárlókat szólítják meg. A vásárlási helyszínek tekintetében azok a fogyasztók a leginkább hajlandóak vásárolni ilyen termékeket, akik az élelmiszer beszerzésüket leginkább az élelmiszer diszkontokban és a szupermarketekben végzik, ami összhangban van azzal, hogy ezek az élelmiszer kiskereskedelmi csatornák egyre dinamikusabban növekednek Magyarországon. 
TöröK, Á.

9. TÁBLÁZAT

TABLE 9

A Hír védjegy rendszeres vásárlását meghatározó tényezók

(Determinants of Frequent Buying of TTR Products)

\begin{tabular}{llc}
\hline $\begin{array}{l}\text { Függó változó } \\
\text { (Dependent variable) }\end{array}$ & $\begin{array}{l}\text { Magyarázó változók } \\
\text { (Independent variables) }\end{array}$ & $\begin{array}{l}\text { Esélyhányadosok, zárójelben az } \\
\text { értékek } \\
\text { (Odds ratios, z-values in parentheses) }\end{array}$ \\
\hline \multirow{2}{*}{$\begin{array}{l}\text { Rendszeres vásárló } \\
\text { (Frequent buyer) }\end{array}$} & Nem (Gender) & $0,202(3,12)^{* * * *}$ \\
\cline { 2 - 3 } & Szupermarket (Supermarket) & $3,405(1,65)^{*}$ \\
\cline { 2 - 3 } & Diszkont (Discounter) & $7,605(2,44)^{* * *}$ \\
\hline
\end{tabular}

Forrás (Source): Saját szerkesztés (Own compilation)

Szignifikancia szintek (Levels of significance): ${ }^{*} \mathrm{p}<0,1 ;{ }^{* *} \mathrm{p}<0,05 ;{ }^{* * *} \mathrm{p}<0,01$

Megjegyzés (Notes): A táblázat csak a szignifikáns eredményeket tartalmazza (Table contains only the significant results)

\section{KöVETKEZTETÉSEK ÉS \\ JAVASLATOK - CONCLUSIONS AND PROPOSALS}

A HÍR védjegy közel 40\%-os ismertsége kifejezetten magasnak tekinthető, mind a HÍR védjegy korábban mért 5-16\%-os ismertségéhez képest (SZÉKELYHIDI et al., 2014; DARVASNÉ ÖRDÖG et al., 2014; TOTTH et al., 2015), mind pedig nemzetközi összehasonlításban is. Az Európai Bizottság megrendelésére az Eurobarometer által készített legfrissebb felmérés szerint az élelmiszer minőséget tanúsító címkék (a felmérésben az alábbi logók ismeretére kérdeztek rá: fairtrade, EU organikus élelmiszer, oltalom alatt álló eredetmegjelölés, oltalom alatt álló földrajzi jelzés és hagyományos különleges termék) átlagos ismertsége 15-37\% között mozgott, s jellemzően a HÍR védjegyhez hasonló alapokon nyugvó földrajzi árujelzók ismertsége a legalacsonyabb (15-18\%). Ebből a szempontból tehát a HÍR védjegy ismertsége kimagaslónak tekinthető. Ugyanakkor csak a fogyasztók 11,36\%-a keresi tudatosan a HÍR védjeggyel ellátott termékeket az élelmiszer vásárlásai során, ami egyben azt is jelenti, hogy a HÍR program céljai egyelőre csak részben teljesülnek, hiszen a magyarországi hagyományos és tájjellegü élelmiszereinek gazdasági hasznosulásához elengedhetetlen, hogy a fogyasztók vásárolják is ezeket a termékeket, ne csak ismerjék a védjegyet. Figyelembe véve, hogy a korábbi kutatások alapján a magyar fogyasztók kifejezetten gyakran vásárolnak szerintük hagyományosnak tekinthető magyar termékeket, a HíR védjegyes termékek gazdasági hasznosításának megvan az alapja.
A HÍR védjegy figyelmen kívül hagyásának leggyakoribb indoka az, hogy a vásárló vagy általánosságban nem hisz a jelölésekben, vagy pedig nincs ideje a jelölésekkel foglalkozni. Ez az eredmény némileg ellentmond a korábbi megállapításokkal, miszerint a magyar fogyasztók az EU átlagot meghaladóan 41 másodpercet töltenek az élelmiszercímkék tanulmányozásával (SZAKÁLY et al., 2014). Ez az idő még mindig kevésnek bizonyul ahhoz, hogy az élelmiszerek címkéin elhelyezett információk (köztük a HÍR védjegy) által közvetített üzenetek célba érjenek. Mivel a HÍR védjegy használatára jogosult termelők leggyakrabban a termék csomagolásán helyezik el a logót (DARVASNÉ ÖRDÖG, 2018), így ez a kommunikációs csatorna nem a leghatékonyabban éri el a célját. Ugyan a HÍR védjegy marketingjének támogatására rendelkezésre álló állami források meglehetősen korlátozottak, a fogyasztókat célzottan más marketing csatornákon keresztül lehetne elérni (SZÉKELYHIDI et al., 2014). A HÍR védjegyes termelők saját bevallásuk szerint még a különböző rendezvények helyszínén jelenítik meg leggyakrabban a logót, s szerintük ennek van a leginkább pozitív hatása a védjegy megítélésére (DARVASNÉ ÖRDÖG, 2018). Ennek a típusú közvetlen értékesítésnek van tehát jelenleg a legnagyobb marketing ereje, így az Agrárminisztérium is leginkább ezeket a kezdeményezéseket tudja támogatni, így például kedvezményes megjelenési lehetőség biztosításával a HÍR védjegyesek számára többek között a kétévente rendezett Országos Mezőgazdasági és Élelmiszeripari Kiállításokon, illetve a Terra Madre Világnaphoz közeli időpontban megrendezett évenkénti Termelői Közösségek Napja 
nevű rendezvényeken. Mindezt alátámasztja a bemutatott felmérés is, hiszen azok a fogyasztók, akik jellemzően közvetlenül a termelőtől szoktak élelmiszert vásárolni, közel két és félszer nagyobb valószínúséggel ismerik a HÍR védjegyet, mint azok, akik nem. Az élelmiszerek csomagolásán szereplő jelölések figyelmen kívül hagyása mellett a HÍR védjegyes termékek elégtelen kínálata és elérhetősége szerepelt még gyakori indokként, ami azt is jelzi, hogy a jelenlegi 92 HÍR védjegy használatára jogosult 176 különböző terméke még nem képvisel akkora súlyt a hazai élelmiszerkínálatban, hogy a fogyasztók nagy hányada keresse tudatosan és célzottan az ezzel a jelöléssel ellátott termékeket.

A HÍR védjegyes termékeket rendszeresen vásárlók aránya a címkét ismerók 38,88\%-a. Ezek a fogyasztók leginkább a különböző húsból készült (nyers és feldolgozott egyaránt) élelmiszereket vásárolják, a felmérés adatai alapján közel minden negyedik válaszadó ilyen típusú terméket jelölt meg, amiből vásárolt olyat, amin szerepelt a tanúsítás. Tekintve azt, hogy a HÍR védjegyes termékek közül csak $8 \%$ tartozik ebbe a kategóriába, megállapítható, hogy a húsok és húskészítmények tekinthetőek a rendszer jelenlegi legnagyobb haszonélvezőinek. Mivel itt a HÍR védjegy használatára jogosultak között (AGRÁRMINISZTÉRIUM, 2018) jelentős méretű vállalkozások (pl.: a gyulai kolbászt előállító Gyulahús Kft.), illetve relatíve nagy potenciális árualappal rendelkező csoportosulások (pl.: a Magyar Szürke Szarvasmarhát Tenyésztők Egyesülete a magyar szürkemarha hússal) is találhatóak, ennek az ágazatnak jelentős lehetőséget biztosíthat a HÍR védjegy. Ugyanakkor a HÍR védjegyesek legnagyobb hányadát kitevő sütőipari termékek (58 db védjegyes termékkel az összes HÍR védjegyes termék $33 \%$-át adva), illetve italok, szörpök (20 védjegyes termékkel 11\%) a felmérés szerint csak ritkán kerülnek be a fogyasztók kosarába. A péktermékek esetében ezt magyarázhatja többek között az is, hogy a magyar fogyasztók a pékáruk, péksütemények címkéinek tanulmányozásával töltik a legkevesebb időt (SZAKÁLY et al., 2014), így az ilyen termékek esetében a csomagoláson (vagy közvetlenül magán a terméken) elhelyezett logó csak korlátozottan tudja elérni a célját. Az italok esetében pedig, ahol leginkább különféle pálinkák jelentik a termékcsoport tagjait, az adhat részben magyarázatot, hogy a jogosult pálinkafőzdék csak ritkán szerepeltetik a védjegyet a termék csomagolásán. Ez alól üdítő kivétel a madarasi pálinka, amelynek üvegén példaértéküen feltüntetésre kerül a HÍR védjegy és adott esetben a KMÉ tanúsító védjegy is.

Azok a fogyasztók, akik ismerik a HÍR védjegyet, vásárlásaikkor keresik is az ilyen logóval ellátott termékeket, leginkább a kínálat elégtelen volta miatt nem vásárolnak akár rendszeresen is ilyen termékeket. Ez a címkék figyelmen kívül hagyásához hasonlóan szintén azt jelzi, hogy jelenleg Magyarországon a HÍR védjeggyel rendelkező, kereskedelmi forgalomban lévő termékek száma nem éri el azt a kritikus tömeget, ami a magyar vásárlóközönséget mérethatékonyan és célzottan el tudná érni. Ezen a HÍR program szellemiségét és alapelveit szigorúan szem előtt tartva két módon lehet változtatni: egyrészt növelni kell a kínálatot új termékek rendszerbe való bevonásával, másrészt pedig ösztönözni kell a már jogosult termelőket, hogy aktívan használják a logót a marketingjük során (a termék csomagolásán kívül egyéb területeken is, például marketing kiadványokban, szóróanyagokon, honlapon). Ugyan a HÍR védjegy jogosultja a minisztérium, igazán hatékony marketinget csak a védjegy használók saját erőforrásainak együttes bevonásával, közösségi marketing akciókban való együttmúködéssel lehetne elérni.

Ami a HÍR védjegy ismeretét befolyásoló tényezőket illeti, az ökonometriai számítások több statisztikailag is szignifikáns összefüggésre derítettek fényt. Először is a nők nagyobb valószínűséggel ismerik fel a címkét, mint ahogyan az idősebb vásárlók is. Előbbi megállapítás összhangban van DOGI és szerzőtársai (2014) eredményeivel, miszerint a nők inkább ismerik az élelmiszervásárlás során előforduló tanúsításokat, míg utóbbi megerősíti azokat a korábbi összefüggéseket, miszerint a hagyományos és tájjellegü élelmiszerek iránt leginkább az idősebb korosztály a fogékony (LAKNER et al., 2009; SZABÓ, 2006, 2009; SZAKÁLY et al., 2008b). A jövedelmi szinteket vizsgálva ugyanakkor megállapítható, hogy minél magasabb a család elkölthető jövedelme, annál kisebb az esélye annak, hogy a HÍR védjegyet 
ismerik. Másképpen fogalmazva, elsősorban az alacsonyabb jövedelmű vásárlók vannak tisztában ezzel a tanúsítással. Ez összecseng egyes nemzetközi szakirodalmi eredményekkel is, miszerint egy bizonyos minőségi szint (és egyben árszínvonal) felett már nem az élelmiszer minőségtanúsító címkék a leginkább meghatározóak (lásd többek között: LOUREIRO és MCCLUSKEY, 2000). Ami a vásárlás helyszínét illeti, több értékesítési csatorna is meghatározó és pozitív hatással van arra, hogy a jellemzően ott vásárló fogyasztók mennyire ismerik a védjegyet. Nem meglepő módon a különböző tanúsításokat amúgy is ismerő, bio boltban vásárló fogyasztók esetében a legnagyobb az esélye annak, hogy ismerjék a tanúsítást. Kiemelt jelentősége van továbbá annak, ha valaki közvetlenül a termelőtől (is) vásárol élelmiszert, hiszen ilyenkor közel két és félszeres eséllyel ismeri a fogyasztó a HÍR védjegyet. Ezt alátámasztja az is, hogy a védjegyhasználó termelők a termék csomagolása mellett leginkább a különböző rendezvények, vásárok helyszínén használják a logót, így itt hatékonyan el tudják érni a fogyasztókat. Az étrendet tekintve a húsfogyasztó (nem vegetáriánus) vásárlók sokkal valószínúbb, hogy ismerik a címkét, ami annak fényében nem meglepő, hogy a megkérdezett fogyasztók leginkább húsokat és húskészítményeket vásárolnak HÍR védjeggyel. Végezetül meg kell jegyezni, hogy a számítások szerint a tojást nem fogyasztók inkább ismerik a védjegyet, mint akik fogyasztanak tojásból készült ételeket.

A címke ismeretével ellentétben a HÍR védjegyes termékek rendszeres vásárlását sokkal kevesebb tényező befolyásolja statisztikailag is kimutatható módon. A regressziós modell szerint ugyan a nők inkább ismerik a védjegyet, rendszeres vásárlókká már kisebb eséllyel válnak, azaz a HÍR védjegyes termékek rendszeres fogyasztói inkább a férfiak közül kerülnek ki. Az értékesítési csatornák tekintetében a jellemzően szupermarketekben és élelmiszer diszkontokban vásárló fogyasztók a leginkább nyitottak az ilyen termékek vásárlására. Tekintve azt, hogy a legutóbbi felmérés (DARVASNÉ ÖRDÖG, 2018) szerint szupermarketekbe mindösszesen 3 , diszkontokba pedig csupán 1 HÍR védjegyes szállít be, itt egy jelentős piaci rés azonosítható be. Ugyan egy ilyen típusú értékesítési csatornába való bekerülés jelentős erőforrásokat igényel a termelő részéről is, a jelenlegi HÍR védjegy használók között több olyan is található (AGRÁRMINISZTÉRIUM, 2018), aki már jelenleg is szállít be ezeknek az áruházaknak, vagy potenciálisan beszállítóvá válhat (pl.: Univer Product Zrt., Paprika Molnár Kft., Gyulahús Kft.). Más kérdés, hogy feltüntetik-e a HÍR védjegyet ezeken a termékeken. Továbbá célzott marketingként ezeknek az áruház típusoknak a vásárlóközönségét megszólítva további jelentős javulás érhető el nemcsak a címke ismertségét, hanem a rendszeres vásárlásokat tekintve is, hiszen egy jellemzően élelmiszer diszkontban vásárló esetében annak az esélye, hogy rendszeresen HÍR védjegyes termék fogyasztó legyen, 7,6-szorosa, míg szupermarket esetében 3,4-szerese annak, mint azoknál a fogyasztóknál, akik jellemzően nem ilyen helyeken vásárolnak.

\section{5. ÖSSZEFOGLALÁS - SUMMARY}

A Hagyományok-Ízek-Régiók (HÍR) program már több mint 20 éve indult el az EU-s Euroterroirs kezdeményezéshez kapcsolódóan Magyarországon, s célja a hagyományos és tájjellegű magyar élelmiszerek ismertségének növelése, illetve gazdasági hasznosulásuk javítása. Mindezeken túl immáron több mint 15 éve bejegyzésre került a HÍR védjegy is, amelynek használatára 2010 óta pályázhatnak a termelők, csoportosulások. A HÍR védjegy használata kézzelfogható termékdifferenciálási eszköz az arra jogosult felhasználóknak. 2018 végén 92 védjegyhasználati jogosult (termelő, csoportosulás) összesen 176 HÍR védjegyes termékkel rendelkezett. A 2015-ben indult Földrajzi Árujelzők Programja (korábban Eredetvédelmi Program) - amely az EU-s földrajzi árujelzőkkel rendelkező magyar termékek számának növelését célozza meg - is alapvetően a HÍR védjegyes termékekre épít, hangsúlyozva ezeknek a termékeknek a jelentőségét. Ugyan a hagyományos és tájjellegü magyar élelmiszereknek jelentős szakirodalma van és a HÍR védjegyes termékek előállítóiról is naprakész információkkal rendelkezünk, a HÍR védjegy és a fogyasztók kapcsolata egy meglehetősen feltáratlan terület. A tanulmány célja éppen ezért 
az, hogy a HÍR védjegy ismertségének, továbbá az ilyen tanúsítással ellátott termékek fogyasztását meghatározó tényezőket beazonosítsa és ismertesse.

Egy nemzetközi felmérés magyarországi részeként a HÍR védjegyhez kapcsolódó online lekérdezés 2017 második felében történt meg, összesen 444 fogyasztó válaszai kerültek elemzésre. Az eredmények alapján elmondható, hogy a HÍR védjegy ismertsége közel 40\%, ami messze meghaladja az EU-s földrajzi árujelzők ismertségének európai átlagát. A HÍR védjegyes termékeket ugyanakkor csak a címkét ismerő fogyasztók alig több mint 10\%-a keresi tudatosan. A HÍR védjegyes termékeket rendszeresen vásárlók leginkább húsból készült élelmiszereket keresnek. Az ökonometriai számítások eredményeként megállapítható, hogy a HÍR védjegyet leginkább a nők, az idősebbek, illetve az alacsonyabb jövedelmi kategóriához tartozó fogyasztók ismerik. A címkét ismerők sokkal nagyobb valószínüséggel kerülnek ki azok közül a vásárlók közül, akik jellemzően bio boltokban, vagy közvetlenül a termelőtől vásárolnak élelmiszert, továbbá akik étrendjüket tekintve nem vegetáriánusok. A HíR védjegyes termékek rendszeres vásárlói leginkább a férfiak, illetve azok a fogyasztók, akik elsősorban szupermarketekben és diszkontokban vásárolnak élelmiszert, $\mathrm{s}$ ez utóbbi bolttípusok emiatt potenciális értékesítési csatornát jelentenek.

\section{KöSZÖNETNYILVÁNÍTÁS - ACKNOWLEDGEMENT}

A szerző ezúton szeretne köszönetet mondani Pallóné Kisérdi Imola Ph.D. címzetes egyetemi docensnek, a HÍR Bíráló Bizottság elnökének a tanulmány megírásához nyújtott szakmai segítségért, továbbá Ching-Hua Yehnek, a Bonni Egyetem munkatársának, a kérdőív összeállításában és a lekérdezés koordinálásában nyújtott szakmai segítségért.

A tanulmány a Bolyai János Kutatási Ösztöndíj támogatásával készült.

$\mathrm{Az}$ Emberi Erőforrások Minisztériuma ÚNKP-18-4 kódszámú Új Nemzeti Kiválóság Programjának támogatásával készült.

A publikációhoz tartozó kutatások elvég- zését és a publikáció elkészítését az NKFIH FK12480o és PD124791 „Az élelmiszer minőségi rendszerek és rövid élelmiszer ellátási láncok gazdasági és társadalmi hatásai Magyarországon” címú pályázat támogatta.

\section{IRODALOMJEGYZÉK - REFERENCES}

Agrárminisztérium: HÍR védjegyesek klubja (2010-2018). 2018.

Áldorfai, G. - Czabadi, L.: Helyi válaszok a globális kihívásokra. Acta Carolus Robertus. 2014. 4 (1064-2016-86458) 9.

Biacs, P. Á. - Szigeti, O.: Innováció és minőség az élelmiszeriparban. Élelmiszer, táplálkozás és marketing. 2006. 3 (1) 5155.

Darvasné Ördög, E. - Székelyhidi, K. Felkai, B. O. - Szabó, D.: Az Európai Uniós és nemzeti élelmiszerminőségrendszerek és védjegyek helyzete Magyarországon. Agrárgazdasági Kutatóintézet, Budapest, 2014. 1-161

Darvasné Ördög, E.: HÍR védjegyes termelők felmérése, különösen az e-kereskedelem vizsgálata. Budapest, 2016.

Darvasné Ördög, E.: A 2017. évi termelői felmérés, valamint a HÍR Program 20122017 közötti értékelése. Budapest, 2017.

Darvasné Ördög, E.: A HagyományokÍzek-Régiók védjegy 2018. évi termelői felmérése. 2018.

Dogi, I. - Nagy, L. - Csipkés, M. - Balogh, P.: Kézműves élelmiszerek vásárlásának fogyasztói magatartásvizsgálata a nők körében. Gazdálkodás. 2014. 58 (2) 160172.

Farnadi, É.: Hagyományok, ízek, régiók: Magyarország hagyományos és tájjellegű mezőgazdasági és élelmiszer-ipari termékeinek gyüjteménye. AMC, Budapest, 2002.

Jasák, H. - Fehér, A. - Szakály, Z.: Fogyasztói preferenciák és attitűdök hagyományos és tájjellegű élelmiszerekkel kapcsolatban. A Marketing Oktatók Klubja 20. Konferenciája. 2014. 372-381 
Juhász, A. - Darvasné Ördög, E. - Jankuné Kürthy, G.: Minőségi rendszerek szerepe a hazai élelmiszergazdaságban. A. K. Intézet, Budapest, 2010.

KSH (KÖZPONTI STATISZTIKAI HIVATAL): Népszámlálás. 2011. http:// www.ksh.hu/nepszamlalas/reszletes_ tablak (Letöltés dátuma: 2018.11.10.)

Lakner, Z. - Bíró, O. - Hajdu, I. Kajári, K. - Kocsondi, J. - Vizvári, B.: A termék-megkülönböztetésre (differenciálásra) épülő stratégia kialakításának és megvalósításának lehetőségei és korlátai a magyar élelmiszerláncban. OTKA Kutatási Jelentések. 2009.

Loureiro, M. L. - McCluskey, J. J.: Assessing Consumer Response to Protected Geographical Identification Labeling. Agribusiness. 2000. 16 (3) 309-320. doi:10.1002/1520$6297(200022) 16: 3<309:$ : a id agr4>3.0.co;2-g

Pallóné Kisérdi, I.: A „HAGYOMÁNYOK - ÍZEK - RÉGIÓK” (HIR) Program eredményei és perspektívái. Élelmiszervizsgálati Közlemények. 2003 a. 49 (4) 216-222.

Pallóné Kisérdi, I.: A versenyképesség biztosításának új minőségi dimenziója az élelmiszergazdaságban EU csatlakozásunk szempontjából, PhD. értekezés, Budapesti Corvinus Egyetem. 2003b.

Pallóné Kisérdi, I.: Személyes interjú (2019.02.20.) 2019.

Popovics, A.: A földrajzi helyhez kapcsolódó és a hagyományos magyar termékek lehetséges szerepe az élelmiszerfogyasztói magatartásban, PhD. értekezés, Szent István Egyetem, Gödöllő. 2009.
Popovics, A. - Gyenge, B.: A földrajzi jelzés oltalmában részesülő magyar termékek ismertsége. Gazdálkodás. 2005. 49 (1) $42-51$.

Popovics, A. - Pallóné Kisérdi, I.: A hagyományos magyar élelmiszerek ismertsége a fogyasztók körében. Élelmiszervizsgálati Közlemények. 2004. 50 (1) $28-36$.

Szabó, E.: Az eredet-és minőségjelzők alkalmazásának lehetőségei és feltételei a marketingkommunikációban, $\mathrm{PhD}$. értekezés, Budapesti Corvinus Egyetem. 2006.

Szabó, E.: Eredet- és minőségjelzők szerepe a marketingkommunikációban. Élelmiszervizsgálati Közlemények. 2009. 55 (1) $43-52$.

Szakály, Z. - Horvát, A. - Soós, M. Pető, K. - Szente, V.: A minőségre és származásra utaló jelölések szerepe a fogyasztói döntéshozatalban. Élelmiszer, táplálkozás és marketing. 2014. 10 (1) 3-10.

Szakály, Z. - Szente, V. - Szigeti, O. - Totth, G. - Polereczki, Z.: A hagyományos magyar élelmiszerek újrapozicionálásának lehetõségei a fogyasztói vélemények tükrében I. Élelmezési Ipar. 2008a. 62 (8) 235-240.

Szakály, Z. - Szente, V. - Szigeti, O. - Totth, G. - Polereczki, Z.: A hagyományos magyar élelmiszerek újrapozicionálásának lehetőségei a fogyasztói vélemények tükrében II. Élelmezési Ipar. 2008b. 62 (8) 265-284.

Székelyhidi, K. - Felkai, B. O. - Darvas, E.: Védjegyek az élelmiszeriparban. Journal of Central European Green Innovation. 2014. 2 (1063-2016-86184) 93. 
Totth, G.: A közösségi marketing lehetőségei a kiegyensúlyozott táplálkozásra irányuló kommunikációban. Élelmiszer, táplálkozás és marketing. 2007. 4 (1) 25-31.

Totth, G. - Hlédik, E. - Zarándné Vámosi, K.: A védjegyek szerepe a vásárlási döntésekben. In: Bíró-Szigeti, Sz. - Petruska, I. - Szalkai, Zs. - Kovács, I. Magyar, M. (szerk.): Marketing hálózaton innen és túl. Az Egyesület a Marketing Oktatásért és Kutatásért XXI. országos konferenciájának tanulmánykötete, Budapest. 2015. 136-144
Zobor, E.: A hagyományos és tájjellegü élelmiszerek közösségielismerésének jogi szabályozása az Európai Unióban. In: Szakály, Z. - Pallóné Kisérdi, I. - Nábrádi, A. (szerk.): Marketing a hagyományos és tájjellegú élelmiszerek piacán. Kaposvári Egyetem, Kaposvár, 2010. 43-50

\section{JEGYZETEK $*$ NOTES}

